\title{
A Leftist Demonstration, on the Asian Bank of the Bosphorus, Two Decades ago
}

\author{
Sinan Çaya, Ph.D. \\ Istanbul University \\ Institute of Marine Administration and Sciences
}

\begin{abstract}
This work is an attempt to analyze - through conventional as well as ethnomethodological and phenomenological methods of Sociology- the social facts behind a youth riot on a labor-day, in Istanbul, in 1996, wherein life and property losses occurred.
\end{abstract}

Key words: Riot; shanty towns; police; policeman; Istanbul.

\section{INTRODUCTION}

On May first 1996, Kadikoy square of Istanbul witnessed some trouble. A riot, supposedly on behalf of the Labor Day, took place. A few people got killed. Many got wounded. Large property destruction came into being. The event, which involved me only at a "tangential point" of touch (1), was a ripe example of a violent incident quite worth of sociological analysis.

The basic sources of information for me were later emissions of TV's and vast numbers of pages of journals and newspapers. Those data were of conventional nature of course. But certain happenings, if concentrated on, were favoring ethno-methodological interpretations (2) much more.

\section{Specific Acts of Violence}

On that day, one conspicuous act was the beating (almost lynching) of a plain clothes policeman by a group which also included female(!) actors. The man had been walking behind the group for some time when they spotted him and started beating him. Now, his walking behind the group is itself worth dwelling on at a sheer analysis by itself.

Ritzer (1983: 342-343 by reference to Ryave \& Schenkein 1974) mentions about walking as a very important example of ethno-methodological study. As a matter fact, here, walking is taken as doing walking rather than just walking. The researchers treated this commonplace phenomenon as a problematic achievement, using a series of video tapes of people walking. In walking, people navigate and avoid collisions. They produce the appropriate walking strategy.

This is a striking example of how, using ethnomethodology, sociologists can take a mundane situation and demonstrate its problematic character. Many skills are involved like maintaining a certain proximity with others. A lone walker avoids the appearance of walking together with a passer-by. He or she takes care not to be regarded as following someone. Laughing, touching, offering cigarettes and similar activities are possible by walking together.

So, in what manner was the disguised policeman walking while following the group in question? Was he sure of himself or even displacing a menacing attitude and thereby disclosing 
(3) his chase? Or, oh the contrary, was he timid and arousing suspicion just because of this appearance? Was he feigning to be one of the rioters themselves in his gait?

Another significant aspect of the beating could be why the police-haters were so ruthless in directing their rage to the person of a single policeman and making him a scapegoat? Here, the primitive vendetta (feud) behavior is easy to detect. Being a representative of the opposing party, he deserved all that in the eyes of the beaters, who, did not bother to stick to the basic principle of individuality of penalty.

Journalists (Milliyet Newspaper May 3, 1996) reported the following scenes: We questioned the 17 or 18-year-old rioters as to who had crashed the shop windows at the Harbor Street. The [justifying] reply was that they were the shops of the bourgeoisie. The journalist expresses his astonishment, emphasizing that they are shops where goods are sold at cheapest prices in the region.

So, at this point, accounts (4) given by the actors are not accepted by the actors and vice versa. Beautiful flowers on the square were tramped and destroyed! Many observers could not understand and accept this vandalism, either.

\section{Fanatics of the Shanty Towns Appear to be Responsible}

Traffic lights and bank automats were shattered. As some journalists put it, an animosity for all symbols associated with city life is observed; the shanty towns (bidonvilles) came to explode.

The suburban shanty towns share little with the cities besides the physical proximity. Their populations (5) are somewhere near the bottom of the Maslow's famous Pyramid of Human Needs. Esthetic aspirations comprise a faraway luxury for those who simply have problems in obtaining basic needs of survival like shelter, food and clothing.

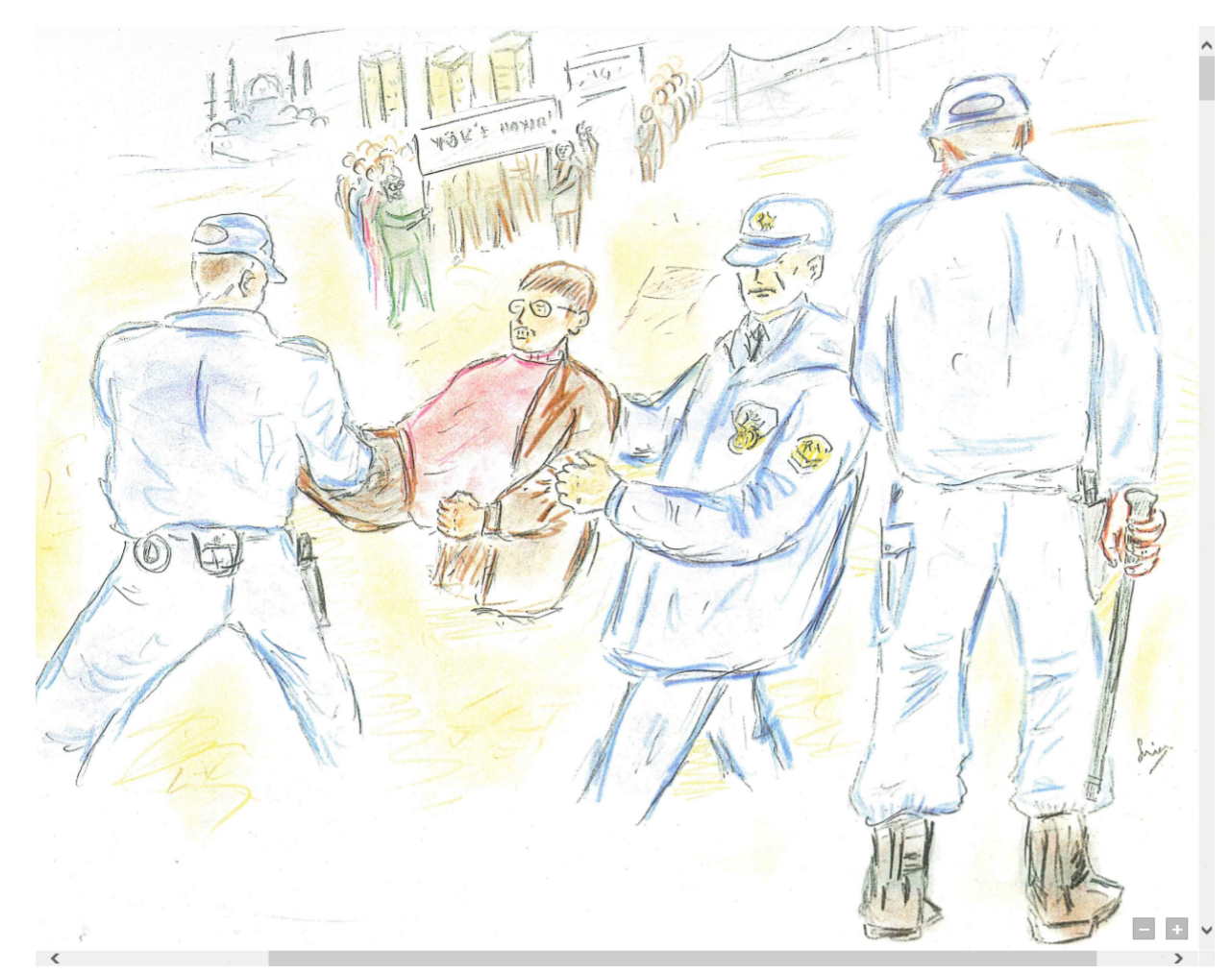

Fig. 1. Policemen rough-handling a rioter in a violent political demonstration (a colored illustration by the author). 
Obviously, young people who can't cope with basic problems and can't postpone their aspirations (like the few who are good at school and nourish hope for future) face many dangers under the temptation to break the constraints imposed by the "establishment". They can be drifted towards crime. They may become religious fundamentalist. They may get mentally deranged. They may keep suffering in silence. However, for sure, they are all full of resentment, which, they know they must suppress in the name of logical thought. But this hatred and resentment can surface at the slightest pretext like the riot in question.

Turkey is a land of contradictions (like many other Third World Countries). Wealth distribution is widely unequal. The children of the poor see all material opportunities of life and crave for them; yet they can't reach them. As columnist Ş. Çizmeci puts it, the gap between the rich and the poor [sometimes seems] insurmountable. The violent participants of that riot were mostly young second generation dwellers of shanty towns. A newspaper used the title "The young (6) Face of Violence".

The authorities seem to be well aware of all the reasons which must have sharpened the feelings of the young. A police chief said: "We put up with their stones and sticks. We prevented worse bloodsheds by not reprising". Late statesman Ecevit, then in opposition, said: "The passionate anger of adolescents really makes one think. Scientists should study that aspect of the youth".

\section{Concluding Remarks and Propositions for the Future}

The problem of shanty towns cannot be ignored any longer. Fortunately; the official tendency is to prevent the formation of further shanty towns at all costs and to resettle the inhabitants in collective housing districts under rapid construction, in just the mid 2000's, does give some present relief and hope for future.

More urgent steps could be taken in education, which pertains to the youth directly (7). Altschull (1995: 246-247) writes that in France, thanks to the centralization in secondary education, the teachers in poor periphery public schools are about at the same level with the teachers in downtown Paris. She praises the unification sense brought about by such practices. As a comparison, she refers to some sport competitions in America, where adolescents from different ethnic origins do horrifying booing and cheering against one another.

\section{Related Notes}

1. While riding to Ankara that morning, I watched the newly gathering mobs in Sögütlüçeşme district through the train window. The anxiety of the security forces had been too obvious since the earlier hours. The taxi I hired with my wife was stopped about a mile before the train station by the police. They did not permit vehicles to go further in the direction of Kadikoy. I had to carry our three suitcases all the way to the station on foot. The Author.

2. "Ethnomethodology studies the process by which people invoke certain taken-forgranted rules about behavior with which they interpret an interaction situation and make it meaningful. To ethnomethodology, in fact, the interpretive process itself is a phenomenon for investigation" (Wallace \& Wolf 1991: 297).

Ever since its birth, sociology is engaged in an unceasing movement of constructing and deconstructing its object. As opposed to the objectivism of Durkheim and his diverse 
counterparts; we also see a subjectivist approach whose central idea is that there is no social activity without intention. Thus; behavior is related not only to the norms or cultural models, but above all, is derived from a subjective sense imposed by the actor himself. Symbolic interactionism as well as phenomenology and ethnomethodology bestow the subject with the privilege of giving sense to the situations he encounters according to his aptitude (Berthelot 1992: 13, 22).

3. It is interesting to note that usually even a plain-clothes policeman heavily relies on his concealed authority in an eventful, or potentially eventful situation. On occasion he might not even care if he is identified or not. In the spring of 1979, I witnessed a peaceful parade-like demonstration of the Progressive Women's Society in Edirne (Adrinople). The social democrat cabinet of late Bulent Ecevit was in power at the moment. Yet, an obvious plain-clothes policeman was taking snap-shots of the parade openly from the very front view with a camera equipped with a long tele-objective. However, there, the demonstrators being all females, expectations of violent consequences were much more feeble possibilities.

4. "Ethno-methodologists devote a lot of attention to analyzing people's accounts, as well as to the ways in which accounts are offered and accepted (or rejected) by others" (Ritzer 1983: 354).

5. At a pedagogy seminar in Ankara (July-August 1986) Educational Sociology instructor Şeren once depicted the shanty town (gecekondu) inhabitant as a distorted type of person, who resembles neither the peasant nor the city-dweller. Displaying admirable moral courage, he brought up himself as a living example!

6. -My long- term socialization process took place in a shanty town in this manner and shaped me accordingly; I cannot ever get rid of that formation; and this is just my bad fate, let me tell you! he added. The Author.

7. The older people possess their own means of coping with deprivation. Some internalize their situation with their fatalistic outlook. Some smoke off or drink off their daily troubles, throttling their frustrations in tobacco and alcohol. Some indulge in lottery games while some invest their hopes in their children (After all, people must always somehow nourish hope for better days to come). Most important of all, having migrated from rural areas, they appreciate the few benefits of the suburbs and are somewhat satisfied with what little they possess here. Their previous circumstances back at the villages were far worse if compared with their prevailing present conditions. The Author

8. The distribution of free textbooks by the state in primary and secondary education, started in mid-2000s for the first time, is a wonderful new application in Turkey. It is an improvement measure comprising very many positive social aspects and it indeed deserves to be praised. 


\section{References}

Altschull, E. (1995). Le voile contre l'école [The Female Head-cover against Schooling], Paris: Éditions du seuil.

Berthelot, J. M. (1992). “La Sociology: Histoire d'une discipline” [Sociology: History of a Social Science Discipline] in Meter, K. M. V. (Ed.): La Sociology, Paris: Larousse.

Milliyet Newspaper (1996), May 03.

Ritzer, G. (1983). Sociological Theory, New York: Alfred A. Knopf.

Şeren, M. (July-August 1986). Unpublished Class Notes in Educational Sociology from Pedagogical In-training Summer Seminar for Secondary School Teachers, Ankara: Gazi University.

Wallace, R. A. \& Wolf, A. (1991). Cotemporary Sociological Theory, Englewood Cliffs-New Jersey: Prentice Hall. 